During the stay at the glacier a cross profile was measured both by theodolite and by hand-level in order to estimate the volume loss due to surface collapse.

The age of lichens on earlier side moraines indicate that a former advance took place 150 to 250 years B. P. .

\title{
K/AR AGE DETERMINATIONS
}

Ole Larsen

In the spring of 1968 we finished setting up and testing the K/Ar dating apparatus at Mineralogisk Museum. A small number of GGU samples were dated during the summer months. Since September a fair amount of time has been spent on testing the suitability of atomic absorbtion spectrophotometry for determining $\mathrm{K}, \mathrm{Rb}$ and $\mathrm{Sr}$. These efforts, however, have not yet been very successful although a considerable amount of experience has been gained. In November and December our main efforts were concentrated on the first attempts at using the solid source mass spectrometer (Atlas $\mathrm{CH}$ 4) at Fysisk Laboratorium II, H. C. Ørsted Institute, for isotope analysis on $\mathrm{Rb}$ and $\mathrm{Sr}$.

K/Ar age determinations were carried out on samples from five different areas in Greenland:

1) The Agto area

Mapping in this area by Vagn Jensen has revealed some occurrences of pseudotachylite in NE-SW-striking major movement zones approximately $20 \mathrm{~km}$ south of Agto (Jensen, 1968). According to Vagn Jensen the movement zones with pseudotachylite are characterized by weak retrogressive metamorphism altering the surrounding enderbitic gneisses into hornblendebiotite gneiss. The whole-rock age of the pseudotachylite, which at the sample locality is still in a vitreous state, was therefore expected to be 
not more than $1750 \mathrm{~m} . \mathrm{y}$, which is the age generally obtained by the $\mathrm{K} / \mathrm{Ar}$ method on rocks in the Nagssugtoqidian fold belt (Larsen and M $\phi 11$ er, 1968). A K/Ar age of $1650 \pm 40 \mathrm{~m}$. y. was measured on biotite from a sample taken near Agto (Larsen and Møller, 1968). The pseudotachylite (GGU 90521) gives a K/Ar date of $3070 \pm 70 \mathrm{~m}$. y. Both $\mathrm{K}$ and Ar determinations have been checked and no great experimental error seems present to explain this extraordinarily high age. High ages ( $>3000 \mathrm{~m}$. y.) have been reported earlier as results of lead isotope studies in the Ivigtut area (Kanasewich and Slawson, 1964) and of Re/Os dating of molybdenite from Fiskenæsset (Herr. et al., 1967). A recent age determination (R. St J. Lambert and J. G. Simons, this report) has shown that the granulite facies metamorphism in the Fiskenæsset area is at least $3210 \mathrm{~m}$. y. old. This date was obtained by K/Ar dating of a hornblende. Possibly the Agto area contains remains of an equally old basement.

2) Midternæs

Four samples of slightly.recrystallized pillow lava from the Ketilidian volcanic series of Midternæs, mapped recently by Higgins (in prep) were chosen for K/Ar dating. The samples vary from fresh basaltic rock of unaltered appearence to thoroughly recrystallized lava with metamorphic growth of zoisite and amphibole. The four samples had very low $\mathrm{K}$ contents and only one sample (GGU 71473) had sufficient $\mathrm{K}$ content for this to be determined with reasonable accuracy by flame photometry. This sample gave an age of only $910 \pm 80 \mathrm{~m}$. y.. The Ketilidian volcanics are cut by a number of Gardar dolerite dykes (approximately $1200 \mathrm{~m}$. y. old, see below), so the age determined on the lava sample is definitely much too low. Methods for determining small amounts of $\mathrm{K}$ will soon be taken into use so that other, possibly more favourable, lava samples may be used for age determination.

3) Grønnedal

In cooperation with C. H. Emeleus (Durham) and R. M. MacIntyre (West Kilbride) we have dated two nepheline syenite samples from the north side of the Grфnnedal-Ika intrusion. In places the rock is quite unaltered by weathering and both biotite and nepheline may be separated for K/Ar dating. The nepheline is being dated by Dr MacIntyre, while age 
determinations on biotite from the two samples have been made in Copenhagen. The two dates obtained on biotite seem to agree within the limits of experimental error: GGU 58311: $1210 \pm 30 \mathrm{~m} . \mathrm{y} .$, GGU 64089: $1170 \pm 35$ m.y. According to Emeleus (1964) the Grфnnedal-Ika intrusion must be placed early in the Gardar period. If we can consider this age of approximately $1200 \mathrm{~m}$.y. as satisfactory for the beginning of the Gardar period, earlier age determinations, especially on samples from Ivigtut, must be reconsidered. As the Ivigtut area seems to be a key area for geochronology in southern West Greenland and detailed maps are now available, we have started a major dating programme for the Ivigtut area and hope to solve also the question of discordant Gardar ages.

\section{4) Tingmiarmiut}

According to D. Bridgwater and K. Gormsen (this report) the basement in the Tingmiarmiut area has a strong resemblance to the IvigtutFrederikshåb gneisses both petrologically and in broad geological setting. It contains inclusions of gabbro-anorthosite and intercalated supracrustal horizons both of which are cut by very weakly metamorphosed dolerites. The supracrustal rocks were metamorphosed in the amphibolite facies. A date of $2190 \pm 50 \mathrm{~m}$. y. was obtained on a sample of small-folded biotitehornblende feldspathic gneiss (GGU 97607) from the migmatite zone separating the basement gneisses from a intercalated supracrustal zone. This date at least sets a minimum for the age of the amphibolite facies metamorphism recorded in the supracrustal rocks, and shows the presence of pre-Ketilidian rocks in South-East Greenland.

\section{5) Scoresby Sund}

Three samples collected in 1967 by N. Henriksen and S. Watt on a reconnaissance survey of the inner Scoresby Sund region have now been dated. According to earlier investigations in the $1950^{\prime} \mathrm{s}$ by $\mathrm{E}$. Wenk and J. Haller (Wenk, 1956 and 1961; Haller and Kulp, 1962) sample GGU 96067, a garnet-kyanite-mica schist from the western part of Fønfjord, and GGU 96036, a biotite-muscovite gneiss from the inner part of Nordvestfjord, should be metamorphic products of Caledonian geosynclinal sedimentation. According to GGU geologists the third sample, GGU 96044, representing 
a biotite-rich intermediate to basic intrusion at the entrance to $\emptyset_{\text {fjord, }}$ was probably emplaced synmigmatitically in the surrounding migmatite. The last sample gives a typical Caledonian age of $435 \pm 12 \mathrm{~m}$. y. A similar age was measured on the gneiss sample GGU 96036, whereas the ages obtained on the schist sample GGU $96067,616 \pm 15 \mathrm{~m}$. y. on biotite and $406 \pm 10$ m. y. on muscovite, are more difficult to interpret. It is however interesting to note that an age of about $600 \mathrm{~m}$. y. is consistent with some of the results from age determinations from the Caledonian fold belt on Spitsbergen (Gayer et al., 1966) where similar ages are interpreted as representing a late Precambrian event. Ages suggesting a late Precambrian thermal event have also been obtained in the Scottish Caledonides and in Scandinavia.

Details of the measurements are given on the following page. 
$\begin{array}{cc}\text { Geographic location } & \text { GGU } \\ \text { sample } \\ \text { no. }\end{array}$

Agto area

Pseudotachylite

$67^{\circ} 47^{\prime}$

Midternæs

Pillow lava

$$
61^{\circ} 34^{\prime}
$$

$\mathrm{N} / 48^{\circ} 09^{\prime}$

W

71473

$61^{\circ} 15^{\prime} 15^{\prime \prime} \mathrm{N} / 48^{\circ} 04^{\prime} 08^{\prime \prime} \mathrm{W}$

$61^{\circ} 15^{\prime} 15^{\prime \prime} \mathrm{N} / 48^{\circ} 04^{\prime} 49^{\prime \prime} \mathrm{W}$

58311

64089

biotite

biotite

8.13

8. 64

0.0993

0.0951

$2.2 / 3.3$

$3.6 / 4.7$

$1210 \pm 30$

Nepheline syenite

$62^{\circ} 32^{\prime}$

$\mathrm{N} / 42^{\circ} 10^{\prime}$

W

97607

biotite

9.04

0.242

$0.29 / 0.4$

$2190 \pm 50$

Scoresby Sund

Intermed. to basic intrusion

Biotite-muscovite gneiss

Garnet-kyanite-mica schist

$\begin{array}{llll}71^{\circ} 13^{\prime} & \mathrm{N} / 25^{\circ} 48^{\prime} & \text { W } & 96044 \\ 71^{\circ} 37^{\prime} & \mathrm{N} / 27^{\circ} 10^{\prime} & \text { W } & 96036 \\ 70^{\circ} 27^{\prime} & \mathrm{N} / 28^{\circ} 15^{\prime} & \text { W } & 96067\end{array}$

Following decay values have been used: $\lambda=5.85 \times 10^{-11}$

$\lambda_{\beta}^{\mathrm{e}}=4.72 \times 10^{-10}$

$\mathrm{K}^{40} / \mathrm{K}=0.0119 \%$ (atomic ratio) biotite $\quad 8.9 \quad 0.0286$

biotite $\quad 8.70 \quad 0.0426$

muscovite

0.0265 biotite $\quad 9.2 \quad 0.0280$ age

$\mathrm{m} \cdot \mathrm{y}$ 。
$1.0 / 1.23070 \pm 70$
16.5
$910 \pm 80$ 
References

Emeleus, C.H. (1964) The Grønnedal-Íka alkaline complex, South Greenland. Bull. Grфnlands geol. Unders., No. 45 (also Meddr Grфnland, Bd. 172, Nr. 3).

Gayer, R.A., Gee, D. G., Harland, W.B., Miller, J.A., Spall, H. R., Wallis, R.H. and Winsnes, T.S. (1966) Radiometric age determinations on rocks from Spitsbergen. Norsk Polarinstitutt Skrifter, Nr. 137.

Haller, J. and Kulp, J.L. (1962) Absolute age determinations in East Greenland. Meddr Grфnland, Bd. 171, Nr. 1.

Herr, W., Wölfle, R., Eberhardt, P. and Kopp, E. (1967) Development and recent applications of the Re/Os dating method. In Radioactive dating and methods of low-level counting. Internat. Atomic. Energy Agency, Vienna, 499-508.

Higgins, A. K. (in prep.) The stratigraphy and structure of the Ketilidian rocks of Midternæs, South-West Greenland. Meddr Grфnland, Bd. $189, \mathrm{Nr} .2$.

Jensen, Vagn (1968) Pseudotachylite in the Agto area. In Report of Activities, 1967. Rapp. Grønlands geol. Unders., Nr. 15, 22-23.

Kanasewich, E.R. and Slawson, W.F. (1964) Precision intercomparisons of lead isotope ratios: Ivigtut, Greenland. Geochim. et Cosmoch. Acta, Vol. 28, 541-549.

Larsen, O. and M $\phi 1 l e r$, J. (1968) K/Ar age determinations from western Greenland I. Reconnaissance programme. Rapp. Grфnlands geol. Unders., Nr. 15, 82-86.

Wenk, E. (1956) Alpines and Ostgrönlandisch-Kaledonisches Kristallin, ein tektonisch-petrogenetischer Vergleich. - Ostgrönlandisches Kaledon. Verh. naturf. Ges. Basel, Bd. 67, 95-99.

Wenk, E. (1961) On the crystalline basement and the basal part of the pre-Cambrian Eleonore Bay Group in the southwestern part of Scoresby Sund. Meddr Grфnland, Bd. 168, Nr. 1. 